Савіна Н. Б. [1; ORCID ID: 0000-0001-8339-1219],

д.е.н., професор

Кузьминчук Н. В. [2; ORCID ID: 0000-0002-9844-3429]

д.е.н., професор

Куценко Т. М. [2; ORCID ID: 0000-0001-7800-2987]

к.е.н., доцент

Нагорний Д. О. [3; ORCID ID: 0000-0003-2503-9799] здобувач вищої освіти третього (освітньо-наукового) рівня

'Національний університет водного господарства та природокористування, м. Рівне

${ }^{2}$ Харківський національний університет імені В. Н. Каразіна, м. Харків ${ }^{3} /$ нститут проблем ринку та економіко-екологічних досліджень НАН України, м. Одеса

\title{
ФАРМАЦЕВТИЧНИЙ МАРКЕТИНГ: ЕКОНОМІКО-ПРАВОВІ ОСНОВИ УПРАВЛІННЯ БРЕНДАМИ НА ФАРМАЦЕВТИЧНОМУ РИНКУ
}

Дослідження спрямоване на розвиток теоретичних засад та розробку практичних рекомендацій щодо удосконалення організаційноправових основ управління брендами на фармацевтичному ринку в контексті фармацевтичного маркетингу. Розвинено теоретичні основи стратегії управління брендами фармацевтичних компаній, що ґрунтуються на класичних моделях управління брендами та передбачають на етапі формування бренду вирішення питання захисту інтелектуальної власності на принципах фармацевтичного маркетингу. За допомогою методів узагальнення та системного аналізу сформовано теоретико-методичні рекомендації щодо організаційно-правових основ управління брендами на фармацевтичному ринку в контексті фармацевтичного маркетингу, реалізація яких дозволить розробити ефективний механізм управління брендами фармацевтичних компаній в умовах ризику та невизначеності через негативний вплив факторів зовнішнього середовища з метою підвищення їх конкурентостійкості.

Ключові слова: маркетинг; організаційно-правові основи; фармацевтичний ринок; фармацевтичний маркетинг; управління брендами.

Актуальність теми. Трансформація регуляторного поля діяльності фармацевтичних компаній в Україні супроводжується суттєвими змінами в принципах, інструментах та методах нормативно-правового та організаційного регулювання фармацевтичного ринку. Знаковим змінами організаційно-правових основ функціонування фармацевтичної галузі стали процеси 
державного регулювання цін на лікарські засоби, ліцензування діяльності суб'єктів господарювання в сфері обігу лікарських засобів, створення системи прозорих державних закупівель продукції фармацевтичних компаній, нагляд за можливими побічними реакціями після вживання лікарських препаратів та забезпечення контролю їх якості. Однак реалізація організаційно-правових змін регуляторного поля фармацевтичного ринку супроводжується поки що не вирішеними проблемами у сфері непрозорих процедур державних закупівель медпрепаратів, лобіювання інтересів потужних гравців ринку, встановлення високих ціна на лікарські засоби тощо. Особливої уваги в системі діяльності представників фармацевтичного ринку в умовах пандемії коронавірусу COVID-19 та пов'язаних 3 нею карантинних обмежень набувають питання маркетингової активності, що в умовах трансформації промоційної діяльності в напрямку збільшення обсягів віддаленої комунікації посилює актуальність формування та реалізації ефективної стратегії управління брендами фармацевтичних компаній у контексті фармацевтичного маркетингу.

Аналіз останніх досліджень і публікацій. Аналіз вітчизняної та зарубіжної літератури показав відсутність єдиного підходу до розуміння особливостей фармацевтичного маркетингу в умовах дії карантинних обмежень та формування ефективних брендинг-рішень. Проте окремі особливості організаційно-правового регулювання фармацевтичного ринку розглянули у своїх працях такі автори, як М. Корчак [2], Р. Федорович [4], І. Чехун [11], Л. Швайка [12], А. Павленко [3], С. Столярова [10]. Маркетингові аспекти просування брендів фармацевтичних компаній в умовах регуляторних впливів $€$ предметом дослідження в роботах вчених, зокрема, таких: І. Чехун [11], Р. Федорович [4], В. Booms [13], М. J. Bitner [13]. Проте, незважаючи на значну кількість наукових праць, недостатньо опрацьованими як у науковому, так і практичному аспектах залишаються питання сутності та методичного інструментарію формування організаційно-правових основ управління брендами на фармацевтичному ринку, а рекомендації щодо їх удосконалення потребують подальшого наукового обґрунтування.

Метою статті $\epsilon$ розвиток теоретичних засад та розробка практичних рекомендацій щодо удосконалення організаційноправових основ управління брендами на фармацевтичному ринку в контексті фармацевтичного маркетингу.

Виклад основного матеріалу. Ключовим фактором, що впливав на розвиток фармацевтичного ринку в 2020 р. стала пандемія коронавірусу та обмеження, пов'язані з введенням карантину, що 
негативно вплинув на загальні результати діяльності фармацевтичних компаній. В квітні-травні 2020 р. спостерігався значний спад ринку, однак в цілому за підсумками 2020 р. обсяг продажів лікарських засобів збільшився на $7 \%$ у грн та $11 \%$ у доларовому еквіваленті, порівняно з 2019 р. Роздрібний сегмент також поступово відновлюється, про що свідчить його зростання на 8\% у грн вже починаючи 3 серпня 2020 р. Наведені дані підтверджують привабливість вітчизняного фармацевтичного ринку для іноземних інвесторів, незважаючи на негативні очікування сповільнення темпів зростання світового фармринку через вплив загального скорочення обсягу світового виробництва та втрат світової економіки через пандемію COVID-19, що за даними МВФ оцінюються на рівні втрати світової економіки 12 трлн дол. в 2020 та $2021 \mathrm{p}$.

Основними викликами для фармацевтичного ринку в короткостроковій перспективі, на думку експертів, стали обмеження закордонних поставок багатьох популярних препаратів через закриті кордони, скорочення обсягів клінічних випробувань та візитів медичних представників у робочий час до медичних закладів. В довгостроковому періоді загрозами стабільній діяльності фармацевтичних компаній стануть обмеження видачі маркетингових посвідчень, скорочення зростання глобального фармринку, розгортання процесу локалізації виробництв, регулювання інтернетторгівлі лікарськими засобами, впровадження реєстраторів розрахункових операцій та недосконалість організаційно-правових основ діяльності фармацевтичних брендів щодо захисту інтелектуальної власності.

Саме нормативно-правове та організаційне забезпечення формування та реалізації маркетингових стратегій управління брендами фармацевтичних компаній в аспекті захисту інтелектуальної власності є найбільш суперечливим та проблемним аспектом діяльності суб'єктів фармацевтичного ринку.

Стратегії управління брендами фармацевтичних компаній ґрунтується на класичних моделях управління брендами, які спрямовані на формування та реалізацію ефективних управлінських рішень щодо створення, оцінювання та подальшого розвитку бренду відповідно до стратегічних цілей його розвитку. На етапі створення бренду важливо підкреслити наочно всі переваги товару, виділити його із загальної маси схожих товарів або послуг у найвигіднішому світлі. Використання брендових товарів дозволяє продавцям залучати досить вигідних покупців, які віддають перевагу товарам певної фірми. Усе частіше у бізнесовому середовищі визріває 
розуміння взаємозв'язку між якісними характеристиками бренду та успішністю бізнесу компанії, що володіє ним. Формування бренду власної продукції або послуг стає базисом подальшого розвитку, сучасним інструментом, який дозволяє підняти бізнес на недосяжний для конкурентів рівень. В цих умовах питання захисту інтелектуальної власності для фармацевтичних компаній особливо гостро постає в процесі прийняття правовласниками рішення про вихід на закордонні ринки і передачі технологій в інші країни. Загальний розмір інвестицій скорочується в тих юрисдикціях, де захист інтелектуальних прав надається на меншому рівні. Таким чином, захист інтелектуальних прав на міжнародному і регіональному рівні в фармацевтичній сфері тісно пов'язана 3 світовим технологічним і культурним розвитком в цілому, створенням, розповсюдженням і використанням існуючих і нових пропрієтарних технологій. Аналіз літературних джерел [2; 4-5; 11 12] із проблем формування організаційно-правових основ управління брендами на фармацевтичному ринку доводить необхідність більш чіткого розмежування поняття «бренд» та «торгова марка», з метою з'ясування їх особливостей та відмінностей в аспекті організаційно-правового регулювання інтелектуальної власності. Відповідно до Закону України «Про охорону прав на знаки для товарів і послуг», торговельною маркою може бути будь-яке позначення або будь-яка комбінація позначень, які придатні для вирізнення товарів (послуг), що виробляються (надаються) однією особою, від товарів (послуг), що виробляються (надаються) іншими особами. Такими позначеннями можуть бути, зокрема, слова, літери, цифри, зображувальні елементи, комбінації кольорів [5]. У свою чергу бренд - це торгова марка, що вже завоювала популярність на ринку і користується попитом у споживачів. Під час реклами брендованого товару у покупця виникають певні асоціації, пов'язані з якістю товару. Також не менш важливою відмінністю $є$ те, що бренд довше залишається на ринку та у пам'яті споживачів, може існувати десятками років, або навіть століттями, брендований товар асоціюється з високою якістю, водночас для торговельної марки це не $€$ обов'язковою умовою. Серед основних нормативних актів, що регулюють правовідносини в системі формування економікоправових основ управління брендами на фармацевтичному ринку, зокрема в сфері захисту інтелектуальної власності, головну роль відіграють акти вищих органів державної влади:

1) центральне місце в структурі формування організаційноправових основ управління брендами на фармацевтичному ринку займає Конституція України, яка проголошує права особистості на 
різнобічне розпорядження своєю власністю та продуктами своєї розумової або творчої діяльності, гарантує захист прав інтелектуальної власності, духовних та матеріальних інтересів, що виникають паралельно з різноманітними видами інтелектуальної діяльності;

2) кодекси України, зокрема Цивільний Кодекс України регулює цивільно-правові та організаційні питання, пов'язані з набуттям, здійсненням та захистом прав інтелектуальної власності;

3) спеціальні закони України: «Про авторське право і суміжні права», «Про розповсюдження примірників аудіовізуальних творів, фонограм, відеограм, комп'ютерних програм, баз даних», «Про охорону прав на винаходи і корисні моделі», «Про охорону прав на промислові зразки», «Про охорону прав на знаки для товарів і послуг», «Про охорону прав на зазначення походження товарів», «Про захист від недобросовісної конкуренції», які регулюють окремі аспекти управління брендами на фармацевтичному ринку та захисту прав інтелектуальної власності;

4) міжнародні договори: Конвенція про заснування Всесвітньої організації інтелектуальної власності, Всесвітня конвенція про авторське право, Паризька конвенція про охорону промислової власності, Мадридська угода про міжнародну реєстрацію знаків, Протокол до Мадридської угоди про міжнародну реєстрацію знаків, Ніццька угода про міжнародну класифікацію товарів і послуг для реєстрації знаків, Договір про закони щодо товарних знаків, Договір про патенту кооперацію, Договір про патентне право, Гаазька угода про міжнародну реєстрацію промислових зразків та ін.

Етапи процесу реєстрації торговельної марки, зокрема на фармацевтичному ринку, регулюються відповідно до чинного законодавства, зокрема, закону України «Про охорону прав на знаки для товарів і послуг». Український інститут промислової власності (Укрпатент) виступає органом виконавчої влади, якому дозволено здійснювати реєстрацію торговельних марок в встановлений термін (від 14 до 18 місяців). Право на реєстраціє торговельної марки на медичні товари та послуги має як фізична, так і юридична особа. На етапі підготовки до реєстрації необхідно визначити, для яких медичних товарів або послуг даний знак буде використовуватися. Обов'язково треба провести дослідження фармацевтичного ринку на існування аналогічних, вже зареєстрованих торговельних марок. 3 16 серпня 2020 р. набули чинності зміни щодо порядку реєстрації, захисту та використанню торговельних марок, а також інші зміни у сфері управління брендами фармацевтичних компаній та захисту інтелектуальної власності [2]. Встановлено реєстр позначень, які 
підлягають реєстрації в якості торговельної марки: форма медичних товарів або їх пакування, звуки якщо вони дозволяють відрізнити товари або послуги одних фармацевтичних компаній від інших, їх зображення, включене в реєстр свідоцтв України на торговельні марки дозволяє в повному обсязі надати правовий захист. Також доповнено перелік торговельних марок, що підлягають реєстрації такими специфічними видами як голографічні, рухові, позиційні та знаки, які являють собою невізуальне позначення (звукові, нюхові, смакові знаки тощо). Перелік специфічних видів торгових марок, які можуть бути використано, в тому числі і фармацевтичними компаніями, визначено Сінгапурським договором про право товарних знаків, що ратифікований Україною в 2009 р., що розширюють межі застосування маркетингу в фармацевтичній сфері за рахунок реалізації креативних та оригінальних підходів до залучення споживачів та створення потужних брендів. Також, доповнено перелік позначень, які не підлягають дії визначеного закону та правовій охороні. Результати аналізу існуючої організаційно-правової бази регулювання відносин в системі регулювання інтелектуального капіталу фармацевтичних компаній дозволяють розробити наступні практичні рекомендації щодо удосконалення правових та організаційних основ управління брендами на фармацевтичному ринку в контексті фармацевтичного маркетингу [15-17]:

1) необхідно розвивати охорону невізуальних позначень, що дозволить фармацевтичним компаніям обрати нестандартні рішення для просування власного бренду, створивши унікальну торгову марку;

2) для формування ефективної стратегії управління брендами на фармацевтичному ринку необхідно подолати складнощі процесу реєстрації результатів інтелектуальної діяльності, які стосуються надмірної бюрократизації (довгий строк оформлення патенту, певні перешкоди при оформленні торгової марки);

3) доцільно встановити чіткі критерії для розрахунку компенсації за порушення авторських прав та визначення розміру відшкодування для особи, яка на законних підставах володіє об'єктами права інтелектуальної власності [4];

4) 3 метою усунення нестабільності умов для раціоналізаторської сфери необхідно більш детально врегулювати правовідносини, що виникають в результаті виконання трудових договорів або договорів про створення за замовленням об'єктів права інтелектуальної власності;

5) удосконалення нормативно-правових актів в частині 
посилення правової охорони об'єктів інтелектуальної власності, організації стимулювання розвитку інноваційної діяльності, поінформованості власників зареєстрованих товарних знаків щодо заявок, які конфліктують з їх товарними знаками.

Наразі в Україні створена сучасна організаційно-правова база управління брендами на фармацевтичному ринку та регулювання правовідносин у сфері інтелектуальної власності, але необхідно продовжувати роботу з їі вдосконалення та гармонізації відповідно до норм міжнародного законодавства.

Висновки. В статті показано, що в умовах уповільнення темпів розвитку глобального фармацевтичного ринку вітчизняні представники фармацевтичної індустрії нарощують обсяги реалізації медичних товарів. Оптимістичні прогнози щодо зростання споживання медикаментів на вітчизняному фармацевтичному ринку дозволяють прогнозувати його повернення до сегменту перспективних ринків, що приваблює іноземних інвесторів.

Обґрунтовано, що важливою умовою підвищення інвестиційної привабливості українського фармацевтичного ринку є необхідність удосконалення організаційно-правових основ управління брендами на фармацевтичному ринку в контексті фармацевтичного маркетингу, що дозволить фармацевтичним компаніям посилювати власні конкурентні позиції та діяти в організаційно-правовому полі захисту інтелектуальної власності.

Наголошено, що стратегії управління брендами фармацевтичних компаній ґрунтується на класичних моделях управління брендами, які спрямовані на формування та реалізацію ефективних управлінських рішень щодо створення, оцінювання та подальшого розвитку бренду відповідно до стратегічних цілей та перспективних напрямів діяльності. Саме на етапі формування бренду власної продукції або послуг для фармацевтичних компаній гостро постає питання захисту інтелектуальної власності на міжнародному і регіональному рівні.

Встановлено основні напрямки удосконалення організаційноправових основ управління брендами на фармацевтичному ринку в контексті фармацевтичного маркетингу, що дозволить підвищити конкурентостійкість фармацевтичних компаній на основі виокремлення існуючих переваг. Перспективами подальших досліджень $є$ розробка та реалізація механізму управління брендами фармацевтичних компаній в умовах ризику та невизначеності через негативний вплив факторів зовнішнього середовища 3 метою забезпечення їх конкурентостійкості. 
1. Економічний енциклопедичний словник: у 2 т. / за ред. С. В. Мочерного. Львів, 2006. Т. 2. 568 с. 2. Корчак М. Медицинский брендинг и маркетинг медицинских услуг в Украине. URL: http://www.medmarketing.ua/blog/medbrending-marketingmeduslug_19 (дата звернення: 20.10.2020). 3. Маркетинговий менеджмент : навч. посіб. / Ф.Котлер, К.Л.Келлер, А. Ф.Павленко та ін. К., 2007. 290 с. 4. Маркетингові стратегії формування попиту на товари та послуги на ринках України / за ред. проф. Р. В.Федоровича. Тернопіль, 2013. 355 с. 5. Належна аптечна практика: стандарти якості аптечних послуг (Спільна настанова МФФ/В003 з НАП). URL: https://zakon.rada.gov.ua/laws/show/897_009\#Text (дата звернення: 20.10.2020). 6. Ожегов С.И. Толковый словарь русского языка: ок. 100000 слов, терминов и фразеологических выражений. М., 2009. 736 с. 7. Про затвердження Державної стратегії реалізації державної політики забезпечення населення лікарськими засобами на період до 2025 року. URL: https://zakon.rada.gov.ua/laws/show/1022-2018-\%D0\%BF\#Text (дата звернення: 20.10.2020). 8. Словник іншомовних слів / за ред. акад. АН УРСР О. С. Мельничука. К., 1985. 968 с. 9. Современный словарь иностранных слов: ок. 20000 слов. М., 2000. 742 с. 10. Столяров С. А. Ринок медичних послуг: деякі його характеристики, проблеми та аспекти управління. Барнаул, 2005. 269 с. 11.ЧехунІ. А. Надання платних медичних послуг: цивільно-правові аспекти. Часопис Київського університету права. 2010. № 2. С. 213-216. 12. Швайка Л. А. Державне регулювання економіки : підручник. К., 2008. 462 с. 13. Booms B., Bitner M. J. Marketing Strategies and Organizational Structures for Service Firms. Marketing of Services. URL: http://www.toolshero.com/marketing/service-marketing-mix-7ps. (accessed: 20.10.2020). 14. MedMarketing. URL: http://www.medmarketing.ua. accessed: 20.10.2020). 15. Коваль В. В., Колеснікова К. С. Сучасні засади економічного аналізу маркетингової діяльності підприємства. Причорноморські економічні студії. 2016. Вип. 3. С. 60-63. 16. Bukanov H., Kolesnyk A., Tashkinova O., Kotlubai V., Koval V. Social marketing in public administration of social service institutions. Revista Genero \& Direito. 2019. Вип. 8. C. 457-468. 17. Mikhno I., Koval V., Ternavskyi A. Strategic management of healthcare institution development of the national medical services market. Access journal, ACCESS Press. 2020. Вип. 1. С. 157-170.

\section{REFERENCES:}

1. Ekonomichnyi entsyklopedychnyi slovnyk : u 2 t. / za red. S. V. Mochernoho. Lviv, 2006. T. 2. 568 s. 2. Korchak M. Medytsynskyi brendynh y marketynh medytsynskykh usluh v Ukrayne. URL: http://www.medmarketing.ua/blog/medbrending-marketingmeduslug_19 (data zvernennia: 20.10.2020). 3. Marketynhovyi menedzhment : navch. posib. / F. Kotler, K. L. Keller, A. F. Pavlenko ta in. K., 2007. 290 s. 4. Marketynhovi stratehii formuvannia popytu na tovary ta posluhy na rynkakh Ukrainy / za red. prof. R. V. Fedorovycha. Ternopil, 2013. 355 s. 5. Nalezhna aptechna praktyka: standarty yakosti aptechnykh posluh (Spilna nastanova MFF/VOOZ z NAP). URL: https://zakon.rada.gov.ua/laws/show/897_009\#Text (data zvernennia: 20.10.2020). 6. Ojegov S. I. Tolkovyiy slovar russkogo yazyika : ok. 100000 slov, terminov i frazeologicheskih vyirajeniy. M., 2009. 736 s. 7. Pro zatverdzhennia Derzhavnoi stratehii realizatsii derzhavnoi polityky zabezpechennia naselennia likarskymy zasobamy na period do 2025 roku. URL: https://zakon.rada.gov.ua/laws/show/10222018-\%D0\%BF\#Text (data zvernennia: 20.10.2020). 8. Slovnyk inshomovnykh sliv / za red. akad. AN URSR 0. S. Melnychuka. K., 1985. 968 s. 9. Sovremennyiy slovar inostrannyih slov : ok. 20000 slov. M., 2000. 742 s. 10. Stoliarov S. A. Rynok 
medychnykh posluh: deiaki yoho kharakterystyky, problemy ta aspekty upravlinnia. Barnaul, 2005. 269 c. 11. Chekhun I. A. Nadannia platnykh medychnykh posluh: tsyvilno-pravovi aspekty. Chasopys Kyivskoho universytetu prava. 2010. № 2. S. 213216. 12. Shvaika L. A. Derzhavne rehuliuvannia ekonomiky : pidruchnyk. K., 2008. 462 s. 13. Booms B., Bitner M. J. Marketing Strategies and Organizational Structures for Service Firms. Marketing of Services. URL: http://www.toolshero.com/marketing/service-marketing-mix-7ps. laccessed: 20.10.2020). 14. MedMarketing. URL: http://www.medmarketing.ua. accessed: 20.10.2020). 15. Koval V. V., Kolesnikova K. S. Suchasni zasady ekonomichnoho analizu marketynhovoi diialnosti pidpryiemstva. Prychornomorski ekonomichni studii. 2016. Vyp. 3. S. 60-63. 16. Bukanov H., Kolesnyk A., Tashkinova O., Kotlubai V., Koval V. Social marketing in public administration of social service institutions. Revista Genero \& Direito. 2019. Vyp. 8. S. 457-468. 17. Mikhno I., Koval V., Ternavskyi A. Strategic management of healthcare institution development of the national medical services market. Access journal, ACCESS Press. 2020. Vyp. 1. S. 157-170.

\title{
Savina N. B. [1; ORCID ID: 0000-0001-8339-1219], Doctor of Economics, Professor, Kuzmynchuk N. V. [2; ORCID ID: 0000-0002-9844-3429], Doctor of Economics, Professor, Kutsenko T. M. [3; ORCID ID: 0000-0001-7800-2987], Candidate of Economics (Ph.D.), Associate Professor, \\ Nahornyi D. O. [4;0RCID ID: 0000-0003-2503-9799], Post-graduate Student
}

\author{
${ }^{1}$ National University of Water and Environmental Engineering, Rivne \\ ${ }^{2}$ V.N. Karazin Kharkiv National University, Kharkiv \\ ${ }^{3}$ Institute of Market Problems and Economic and Ecological Research of the National \\ Academy of Sciences of Ukraine, Odessa
}

\section{PHARMACEUTICAL MARKETING: ECONOMIC AND LEGAL FRAMEWORK FOR BRAND MANAGEMENT IN THE PHARMACEUTICAL MARKET}

The research is aimed at developing theoretical foundations and developing practical recommendations for improving the legal framework for brand management in the pharmaceutical market in the context of pharmaceutical marketing. It has been substantiated that in order to increase the investment attractiveness of the domestic pharmaceutical market, it is necessary to improve the legal framework for brand management in the pharmaceutical market, which will allow pharmaceutical companies to strengthen their competitive positions in the international and regional markets and operate in the legal field of intellectual property protection.

The theoretical foundations of the brand management strategy of pharmaceutical companies are developed, based on classical models of 
Серія «Економічні науки»

Випуск 4(92) 2020 p.

brand management, which provide for the possibility at the stage of brand formation to resolve issues of intellectual property protection.

With the help of methods of generalization and system analysis, theoretical and methodological recommendations were formed on the legal foundations of brand management in the pharmaceutical market in the context of pharmaceutical marketing, the implementation of which will allow developing an effective mechanism for managing brands of pharmaceutical companies in conditions of risk and uncertainty as a result of the negative influence of environmental factors in order to ensure their competitiveness.

Keywords: marketing; legal framework; pharmaceutical market; pharmaceutical marketing; brand management.

Савина Н. Б. [1; ORCID ID: 0000-0001-8339-1219], д.э.н., профессор

Кузьминчук Н. В. [2; ORCID ID: 0000-0002-9844-3429],

д.э.н., профессор,

Куценко Т. М. [2; ORCID ID: 0000-0001-7800-2987], К.э.Н., доцент,

Нагорный Д. О. [3; ORCID ID: 0000-0003-2503-9799] соискатель высшего образования третьего (образовательно-научного) уровня

${ }^{1}$ Национальний университет водного хозяйства и природопользования, г. Ровно

${ }^{2}$ Харковский национальный университет имени В. Н. Каразина, г. Харьков

${ }^{3}$ Институт проблем рынка и экономико-экологических исследований НАН Украины,

г. Одесса

\title{
ФАРМАЦЕВТИЧЕСКИЙ МАРКЕТИНГ: ЭКОНОМИКО-ПРАВОВЫЕ ОСНОВЫ УПРАВЛЕНИЯ БРЕНДАМИ НА ФАРМАЦЕВТИЧЕСКОМ PЫHKE
}

\begin{abstract}
Исследование направлено на развитие теоретических основ и разработку практических рекомендаций по совершенствованию организационно-правовых основ управления брендами на фармацевтическом рынке в контексте фармацевтического маркетинга. Обосновано, что с целью повышения инвестиционной привлекательности отечественного фармацевтического рынка необходимо совершенствовать организационно-правовые основы управления брендами на фармацевтическом рынке, что позволит фармацевтическим компаниям усилить конкурентные позиции на международном и региональном рынках и действовать в организационно-правовом поле защиты интеллектуальной собственности.

Развиты теоретические основы стратегии управления брендами фармацевтических компаний, основанные на классических моделях
\end{abstract}


управления брендам, предусматривающие возможность на этапе формирования бренда решать вопросы защиты интеллектуальной собственности.

С помощью методов обобщения и системного анализа сформированы теоретико-методические рекомендации по организационно-правовым основам управления брендами на фармацевтическом рынке в контексте фармацевтического маркетинга, реализация которых позволит разработать эффективный механизм управления брендами фармацевтических компаний в условиях риска и неопределенности в результате негативного влияния факторов внешней среды с целью обеспечения их конкурентостойкости.

Ключевые слова: маркетинг; организационно-правовые основы; фармацевтический рынок; фармацевтический маркетинг; управление брендами.

Стаття надійшла до редакції 17.12.2020 р. 